\title{
Effect of abiotic variables on fish eggs and larvae distribution in headwaters of Cuiabá River, Mato Grosso State, Brazil
}

\author{
Simoni Ramalho Ziober ${ }^{1,2}$, Andréa Bialetzki ${ }^{3}$ and Lúcia Aparecida de Fátima Mateus ${ }^{2}$
}

Researches on ichthyoplankton seems to be an important tool to identification of spawning areas and periods for freshwater fish. Ichthyoplankton was sampled monthly in the headwaters of the Cuiabá River, upper Paraguay River basin, (Mato Grosso State, Brazil), and in four of its tributaries, between November 2007 and March 2008, to evaluate the spatial and temporal distribution of fish eggs and larvae and the influence of regional and local variables on their distribution. In total, 22,067 eggs and 1,045 larvae were collected. A significant negative correlation was found between egg density and the variables of river level and flow volume. Larval density was not significantly correlated with any of the regional variables. The egg and larval densities were significantly higher at the sampling sites in the main river. The highest densities were found in environments with greater river widths, intermediate depths and lowest values of dissolved oxygen, electrical conductivity, and transparency. Anostomidae, Zungaro zungaro, Bryconamericus spp., Pimelodus spp., Pimelodidae, Auchenipteridae, and Siluriformes were the most abundant groups of larvae, and were observed at the sampling sites in the main river. The study site is an important spawning area for migratory and, non-migratory fish species, and highlight the importance of the main river to the reproductive event, by the influence of local variables transparency and river width, which in turn maybe temporally influenced by the river level.

O estudo do ictioplâncton tem se mostrado uma importante ferramenta na identificação de áreas e períodos de desova para as espécies de peixes de água doce.Amostragens de ictioplâncton foram realizadas mensalmente na região de cabeceira do rio Cuiabá, bacia do alto rio Paraguai, (Mato Grosso, Brasil) e em quatro de seus tributários, entre novembro de 2007 e março de 2008 , com o objetivo de avaliar a distribuição espaço-temporal de ovos e larvas de peixes. Foram amostrados 22.067 ovos e 1.045 larvas. Identificou-se correlação significativa e negativa entre a densidade de ovos, o nível fluviométrico e a vazão. A densidade de larvas não apresentou correlação significativa com nenhuma das variáveis regionais. As densidades, tanto de ovos quanto de larvas, foram significativamente maiores nos pontos no rio principal. As maiores abundâncias foram observadas em ambientes com maiores valores de largura do rio, valores intermediários de profundidade e menores valores de $\mathrm{O}_{2}$ dissolvido, condutividade e transparência. Os grupos taxonômicos de larvas mais abundantes foram Anostomidae, Zungaro zungaro, Bryconamericus spp., Pimelodus spp., Pimelodidae, Auchenipteridae e Siluriformes, com maiores abundâncias observadas nos pontos no rio principal. Os resultados mostram que o local de estudo é uma importante área de desova para as espécies de peixes migradores e não-migradores, e destacamos a importância do rio principal para o evento reprodutivo, pela influência das variáveis locais, transparência e largura do rio, que por sua vez parecem ser influenciadas temporalmente pelo nível fluviométrico.

Key words: Freshwater fishes, Ichthyoplankton, Spatial-temporal distribution, upper Paraguay basin.

\section{Introduction}

The reproduction of most teleosts shows annual periodicity, with spawning occurring when the conditions are favorable for the survival of offspring (especially those related to food supply, shelter and availability of space) (Castro et al., 2002). Therefore, an understanding of the reproductive dynamics of the fish community and its relationship with the environment is facilitated by knowledge of spawning areas and periods (Bialetzki et al., 2004). Many species develop reproductive migrations from the lower reaches of rivers to the headwaters, where they usually seek areas close to springs to reproduce, and generally deposit their spawn in the main channel (Lowe-McConnell, 1999; Agostinho \& Júlio Jr., 1999). After spawning, the fertilized eggs are transported passively downriver, where they find

\footnotetext{
${ }^{1}$ Universidade Federal de Santa Catarina, Programa de Pós-Graduação em Aquicultura, Centro de Ciências Agrárias. Rodovia Admar Gonzaga, 1346, Itacorubi, 88034-001 Florianópolis, SC, Brazil.

${ }^{2}$ Universidade Federal de Mato Grosso, Instituto de Biociências, Laboratório de Ecologia e Manejo de Recursos Pesqueiros (LEMARPE). Av. Fernando Corrêa da Costa, CCBS-II/Anexo, s/n- Coxipó, 78060-900 Cuiabá, MT, Brazil. lmateus@ufmt.br (LAFM) ${ }^{3}$ Universidade Estadual de Maringá, Núcleo de Pesquisas em Limnologia, Ictiologia e Aquicultura (NUPÉLIA). Av. Colombo, 5790, Bloco G-90, 87020-900 Maringá, PR, Brazil.
} 
sites with favorable conditions for their development (Nakatani et al., 1997; Gomes \& Agostinho, 1997), such as marginal lakes in the floodplains (Ziober et al., 2007). We must also consider that in embedded rivers, that have no floodplains, the larval development may occur in backwaters, like the mouth of tributaries, that are dammed by the main river during the flood period, as observed by Zaniboni-Filho \& Schulz (2003) in Uruguai River.

The main reasons for migration are probably adaptations to enhance survival and growth rates and to maximize fitness, which is increased by movement among different habitats that support variable needs during ontogeny (Jonsson, 1991), and to allow for colonization of alternative areas for the food supply and dispersion of species, which leads to increased survival (Pavlov et al., 1978).

The drifting of fish larvae from spawning to nursery grounds is an important behavioral mechanism in the early development of freshwater fish, which ensures the dispersion of populations in fluvial ecosystems (Penáz et al., 1992), and is also related to growth, survival and recruitment success (Copp et al., 1992). Hence, information about the location, dimensions and characterization of spawning areas and growth is essential for management actions aimed at increasing fishing production or species preservation (Nakatani et al., 2001).

The hypothesis of this study is that the fish reproduction rather occurs in places and times that favor the dispersion and initial development of the young forms, such as those with increased outflow, or high levels of dissolved oxygen. So, the purpose of this study is to evaluate the distribution of ichthyoplankton at the headwaters of the Cuiabá River, linking their density with environmental variables. The specific aims are: i) to analyze the and temporal and spatial distribution of ichthyoplankton, correlating their density with regional and local variables respectively; ii) to evaluate the relative importance of water bodies (main river or tributary) as spawning sites; iii) to describe the composition of the ichthyoplankton and evaluate the temporal and spatial difference (river and tributary) among the most abundant taxonomic groups of collected larvae.

\section{Material and Methods}

Study area. The Cuiabá River is about $850 \mathrm{~km}$ long and drains a basin of about $100,000 \mathrm{~km}^{2}$. This river belongs to Paraguay basin and is one of the tributaries of this river, which, together with the São Lourenço, Piquiri, Taquari, Miranda and Negro Rivers, seasonally overflows and floods an area of approximately $150,000 \mathrm{~km}^{2}$, and is therefore one of the main formers of the Pantanal floodplain (Cavinatto, 1995). Its headwaters are located in the Rosario Oeste city, state of Mato Grosso, on the slopes of the Serra Azul mountain range, and its main sources are the Cuiabá da Larga and Cuiabá do Bonito Rivers. The river formed by the confluence of these two rivers is called Cuiabazinho River, which in turn joins the Manso River, giving rise to Cuiabá River. The study area comprises the region of the Cuiabazinho River located near the municipalities of Nobres and Rosário Oeste, located approximately $190 \mathrm{~km}$ from Cuiabá city, Mato Groaao State. This area encompasses the surroundings of the springs downstream from the confluence of the Cuiabá da Larga and Cuiabá do Bonito Rivers, until upstream to the proximities of its confluence with the Manso River (Fig. 1).

Data collection and analysis. Samples were collected monthly, in the reproductive period of the most species of the region (November to March), in the year 2007/2008, at eight sampling sites (Fig. 1). Four of which were located in the Cuiabazinho River and four in tributaries on the right (Cuiabazinho and Quebó streams) and left margins (Água Fina and Triste streams) of this river. The sampling sites in the Cuiabazinho River were dubbed CBZ I, CBZ II, CBZ III and CBZ IV, according to their positions in the river, in other words, the most upstream point was dubbed CBZ I, and so on. All the sites in the main river close to the tributaries were located at a distance of approximately $200 \mathrm{~m}$ upstream from their confluence. The site CBZ I was not sampled in November due to logistical problems.

Passive sampling was carried out at night close to 8:00 p.m. (because it is the time of most reproductive activity), using cylindrical-conical plankton nets with $500 \mu \mathrm{m}$ mesh, 1.5 $\mathrm{m}$ in length, an opening of $0.1104 \mathrm{~m}^{2}$, with a General Oceanics ${ }^{\mathrm{TM}}$ mechanical flow meter coupled in its entrance, to measure the volume of filtered water. The nets were placed at the subsurface of the water, using a transverse cable attached perpendicularly to the river bed, and left there for 10 minutes to capture drifting eggs and larvae. Three simultaneous sampling were made at the sites located in the Cuiabazinho River (margins and mid-channel), while samples from the tributaries were collected only mid-channel because they are narrower than the main river. In the field, the samples were fixed in $4 \%$ formalin buffered with $\mathrm{CaCO}_{3}$. Simultaneously, the physical and chemical variables of the water (temperature, dissolved oxygen, $\mathrm{pH}$, electrical conductivity, transparency - except to January -, flow rate at the entrance of the net, width of the river and its depth at 5-meter intervals at the sampling point), called the local variables, were measured at the sampling sites. The regional variables of river level, outflow and rainfall were obtained from the Superintendência de Defesa Civil do Governo do Estado de Mato Grosso, with data from the rainfall station in the city of Rosário Oeste.

The samples were screened in the laboratory, the individuals were counted and their density standardized for a volume of $10 \mathrm{~m}^{3}$ of filtered water, according to Tanaka (1973). The larvae were identified down to the lowest possible taxonomic level, as described by Nakatani et al. (2001). The larvae identified at the lowest taxonomic level were classified according to their parents' reproductive strategy (migratory or non-migratory), following Suzuki et al. (2004).

The temporal distribution of eggs and larvae was analyzed using a Spearman correlation between the egg and larvae densities and the regional variables. In the case of egg densities, 


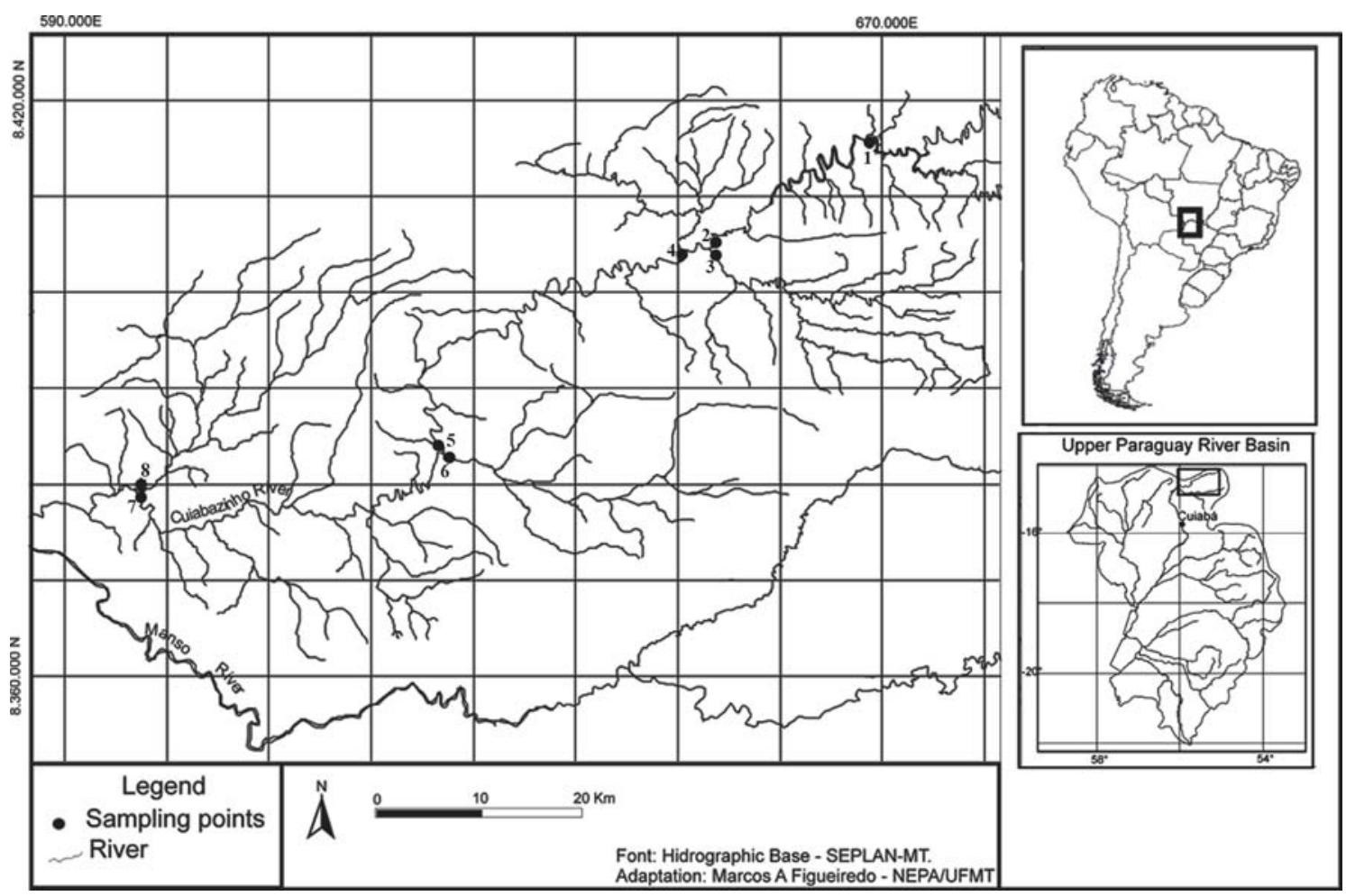

Fig. 1. Location of the sampling sites. 1= Cuiabazinho River (CBZ I, 14²0'13.8”S 55'29'42.5'W); $2=$ Cuiabazinho River (CBZ II,

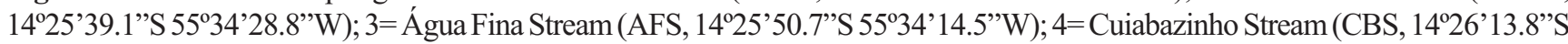

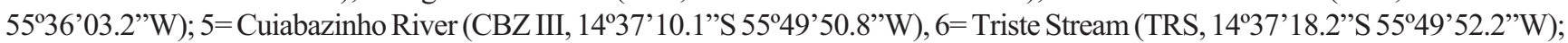
7= Cuiabazinho River (CBZ IV, 14³9'15.8”S 5607'52.2’W); 8= Quebó Stream(QBS, 14³9'14.9”S 5607'49.3”W).

the measures of these variables on each of the collection days were correlated with the density of eggs collected on the same days, based on the principle that these variables directly influenced spawning on the collection days. In the case of larval densities, it was considered that the variables did not exert a direct influence on the collection day, since the captured larvae would come from spawn deposited on previous days. Therefore, an average was calculated of the values of the variables in each of the sampling months, which was then correlated with the average larval density in those months.

The influence of local variables on the spatial distribution of ichthyoplankton was evaluated using a Principal Components Analysis (PCA) to reduce the dimensionality of these variables. The values of these variables were first logtransformed $(\log x+1)$ to reduce the difference between the scales. The axes of the PCA with eigenvalues higher than 1.0 were accepted for interpretation, according to the KaiserGuttman criterion (Jackson, 1993). Only variables with "loads" exceeding 0.7 were considered as formers of the PCA axes. Two univariate multiple regression models were then applied between the most explanatory axes of the PCA and the logarithmized density of eggs and larvae, with the scores of the PCA axes being the independent variables and the densities the dependent variables. The sites sampled in January were not included in this analysis due to the absence of transparency data in that month, which prevented the PCA from generating the scores.

A Hierarchical Variance Analysis (nested ANOVA) was used to evaluate the difference in egg density between the months and between the sites classified into river $(\mathrm{R})$ and tributary $(\mathrm{T})$ (nested with the variable month). To this end, the egg density values were logarithmized $(\log (\mathrm{x}+1))$ to meet the assumptions of the analysis (the normality was tested by the KolmogorovSmirnov test and the variance homogeneity by Levene test). For larvae, in the analysis of both total density and the most abundant taxonomic groups, the logarithmization of the densities was not sufficient to meet these assumptions, thus requiring nonparametric tests to answer the question. The Kruskall-Wallis test was therefore used to evaluate the difference in larval density among the months, and the MannWhitney test to evaluate the difference among sites (river and tributary). In this case, because two statistical tests were needed to rest the hypothesis of spatial-temporal difference, the level of significance was corrected using the Bonferroni Correction, considering as significant the tests that presented $\mathrm{p}<0.025$. The STATISTICA v. 7.0 (Statsoft, 1999) software was used for the Spearman correlations, nested ANOVA, PCA and regressions. The SYSTAT v. 12.0 (Wilkinson, 2007) software was used for the Kolmogorov-Smirnov, Levene, Kruskall-Wallis and Mann-Whitney tests. 


\section{Results}

Effect of regional variables in temporal distribution of ichthyoplankton. During the sampling period 22627 eggs (95.5\% of the total of ichthyoplankton) and 1045 larvae were captured. In every month, eggs were more abundant than larvae. The highest egg captures occurred in November and December, and the highest density was recorded in December (1276.42 eggs/ $\left.10 \mathrm{~m}^{3}\right)$. Larvae were more abundant in January, with 53.58 larvae/ $10 \mathrm{~m}^{3}$. The lowest values of both eggs and larvae were observed in March (0.35 eggs $/ 10 \mathrm{~m}^{3}$ and 0.11 larvae $/ 10 \mathrm{~m}^{3}$ ) (Fig. 2a).

The river level and outflow presented their lowest values in November $\left(0.87 \mathrm{~m}\right.$ and $181.08 \mathrm{~m}^{3} / \mathrm{s}$, respectively) and their highest ones in February $\left(4.10 \mathrm{~m}\right.$ and $858.68 \mathrm{~m}^{3} / \mathrm{s}$, respectively) (Figs. 3a-b). January recorded the highest rainfall and December the lowest, with several records of absence of rain (Fig. 3c). A negative significant correlation was found between egg density and the variables of river level $(\mathrm{rs}=-0.49 ; \mathrm{p}<0.05)$ and outflow $(\mathrm{rs}=-0.46 ; \mathrm{p}<0.05)$.
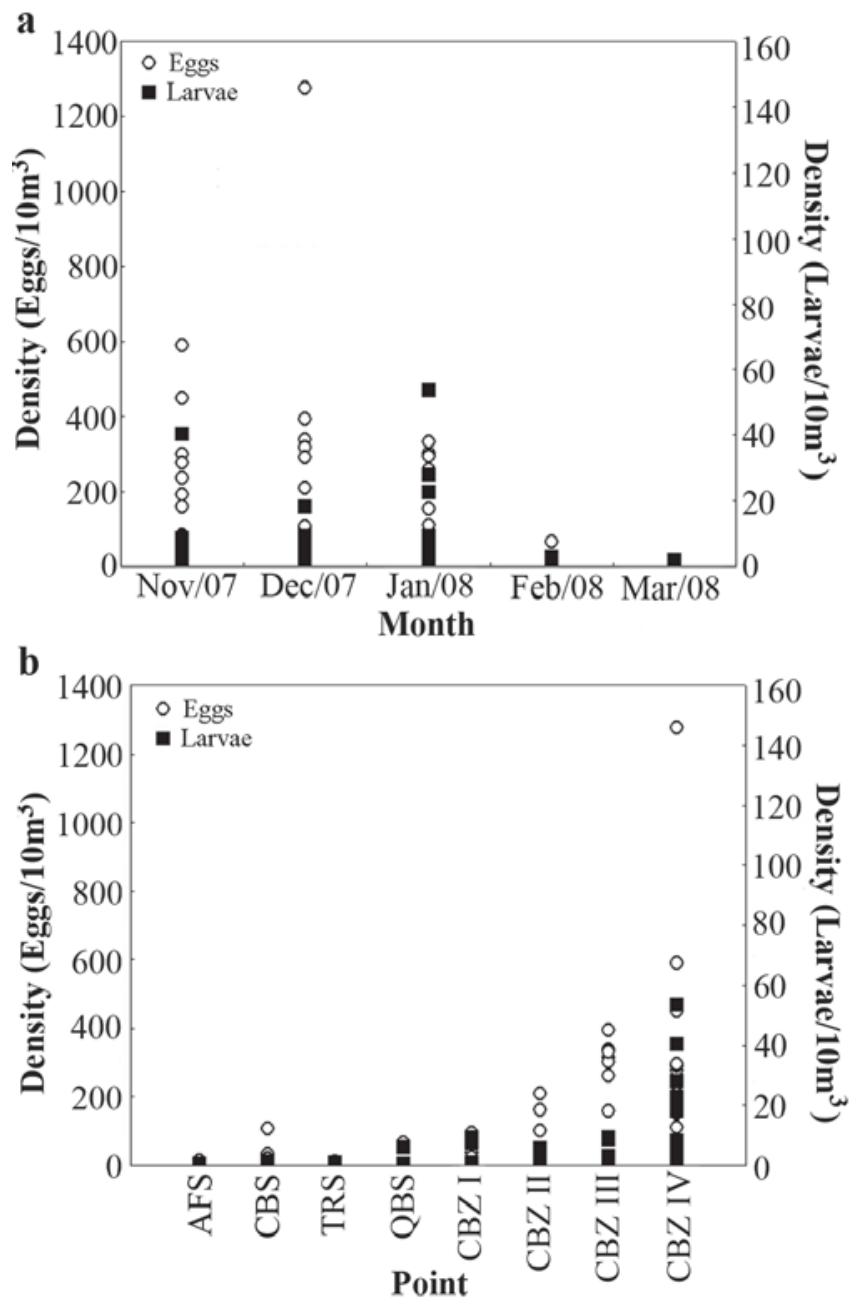

Fig. 2. Temporal (a) and spatial (b) distribution of density (individuals $/ 10 \mathrm{~m}^{3}$ ) of fish eggs and larvae captured in the headwaters of the Cuiabá River, in all the collection sites, between November 2007 and March 2008.
However, larval density showed no significant correlation with any of the regional variables.

Effect of local variables in spatial distribution of ichthyoplankton. The highest densities of both eggs and larvae occurred at the sites located in the Cuiabazinho River, both of which were more abundant at point CBZ IV (1276.42 eggs $/ 10 \mathrm{~m}^{3}$ and 53.58 larvae $/ 10 \mathrm{~m}^{3}$ ) (Fig. 2b).
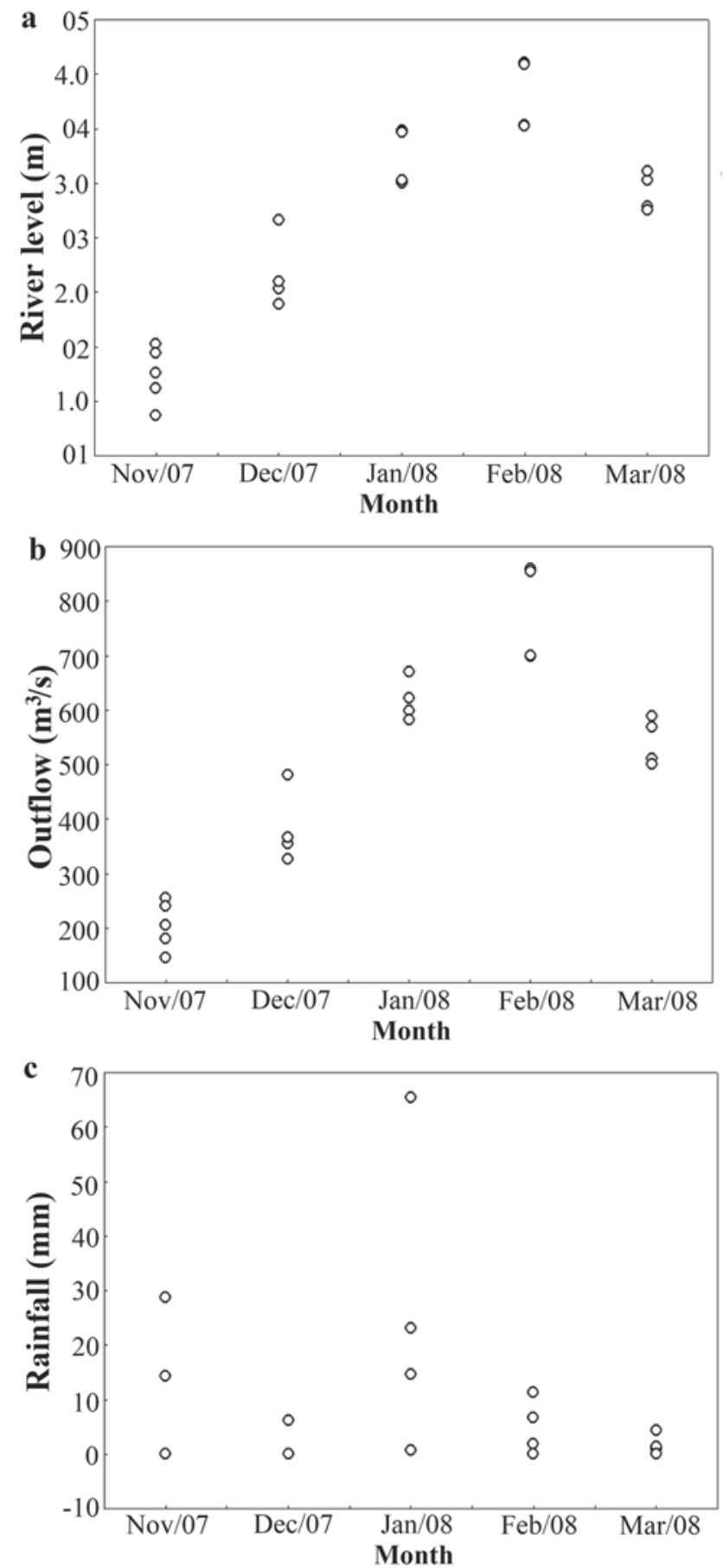

Fig. 3. Values of the regional variables of river level (a), outflow (b), and rainfall (c), obtained in the region of Rosario Oeste between November 2007 and March 2008. 
With regard to local variables, no major variation was found in the values of temperature and dissolved oxygen (Fig. 4a). The $\mathrm{pH}$ showed the lowest values at point CBZ I and the highest at point QBS, while electrical conductivity showed a wide range of variations, with the lowest values at point CBZ II and the highest at point QBS (Fig. 4b). Transparency values were generally higher in tributaries, with the highest values recorded at point QBS and the lowest at CBZ II (Fig. 4c). As for flow velocity, the highest value was recorded at point CBZ II and the lowest at point CBS (Fig. 4c). The river depth showed the highest value at point TRS and the lowest at point AFS (Fig. $4 d)$. In terms of river width, the highest value was recorded at point CBZ IV and the lowest at point CTR (Fig. 4d).

The first axis of the PCA captured $30.80 \%$ (eigenvalue: 2.46) of the variation of the local variables data, while the second captured $21.16 \%$ (eigenvalue: 1.69 ). Dissolved oxygen (0.76), electrical conductivity (0.71), transparency (0.74), and river width $(-0.73)$ were correlated to the first axis. However, only the variable depth $(-0.83)$ was correlated to the second axis. The univariate multiple regression models applied to the logarithm of egg and larval densities (response variables) and to the scores of the axes of the PCA (explanatory variables) indicated a significant joint effect of the two axes on both egg $\left(\mathrm{F}_{2.27}=4.84 ; \mathrm{R}^{2}=0.26 \mathrm{p}=0.01\right)$ and larval $\left(\mathrm{F}_{2.27}=4.72 ; \mathrm{R}^{2}=0.26\right.$ $\mathrm{p}=0.01$ ) density. However, when analyzed separately, only axis 1 presented a significant negative effect on the density of both eggs $(b=-0.41 ; p<0.01)$ and larvae $(b=-0.11 ; p=0.01)$.

A graphic analysis of the PCA scores indicated a spatial and temporal difference between the sites. The highest densities were observed in environments with higher values of river width, intermediate values of depth and lower values of dissolved oxygen, electrical conductivity and transparency (D2, N5, D5, D7, and N7). The lowest densities were recorded in environments with the highest values of dissolved oxygen, electrical conductivity, transparency (N6, D6, F6 M6, N8, D8, F8, and M8) and at both high (F5, F7) and low depths (N2, N3, N4, and D4) (Fig. 5).

There was a significant difference in egg density among the sampling months $\left(\mathrm{F}_{4.29}=6.13 ; \mathrm{p}=0.001\right)$ and among sites $\left(\mathrm{F}_{5.29}=4.00 ; \mathrm{p}=0.006\right)$. In the month of highest density
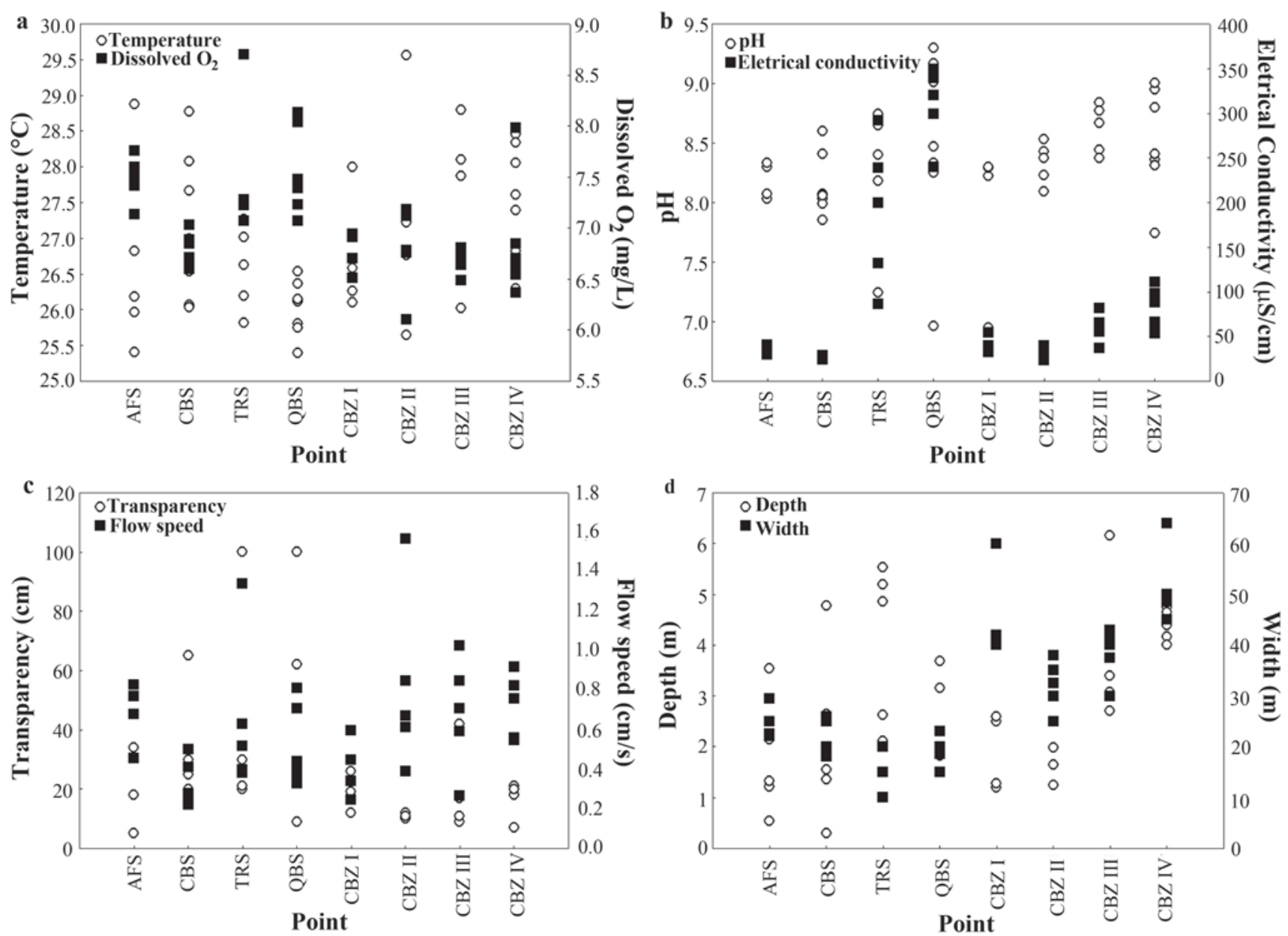

Fig. 4. Values of the local variables of temperature and dissolved oxygen (a), $\mathrm{pH}$ and electrical conductivity (b), transparency and flow velocity (c), and width and depth (d), obtained in the headwaters of the Cuiabá River between November 2007 and March 2008. 
(December), a gradient was observed in the distribution of eggs along the Cuiabazinho River, with average densities increasing from upstream to downstream. This pattern was not found in the tributaries, and the egg densities at these sampling sites were usually low. However, two peaks in mean egg density were observed: one at point CBS in December and the other at point QBS in February. In the case of larval density, no significant difference was found among the months $(\mathrm{H}=5.11 ; \mathrm{p}=0.28)$, but the density was different among sites (Mann-Whitney: $U=3.08$; $\mathrm{p}=0.001$ ). Larvae were generally captured in much lower densities than eggs, but there was a considerable capture of larvae at point CBZ IV in January. Among the tributaries, the point with the highest mean density was QBS, in November.

Taxonomic composition. The larvae captured during the sampling period belonged to the orders Characiformes, whose contribution represented $6.2 \%$ of the captures, Siluriformes, $84.5 \%$ and Gymnotiformes, only $0.5 \%$ of the captures. Damaged and unidentified larvae accounted for $8.61 \%$. Seven taxa were identified among the order Characiformes, and the taxa with the highest density were Anostomidae, followed by Bryconamericus spp. Two species of long-distance migratory Characiformes were found: Prochilodus lineatus and Salminus brasiliensis. Among the Siluriformes, eleven taxa were identified, but the highest contribution was of newlyhatched larvae of Siluriformes, followed by unidentified Auchenipteridae and Pimelodus spp. Three taxa of longdistance migratory Siluriformes were observed: Hemisorubim platyrhynchos, Pseudoplatystoma spp., and the most abundant, Zungaro zungaro. The contribution of Gymnotiformes was very small, with only one individual

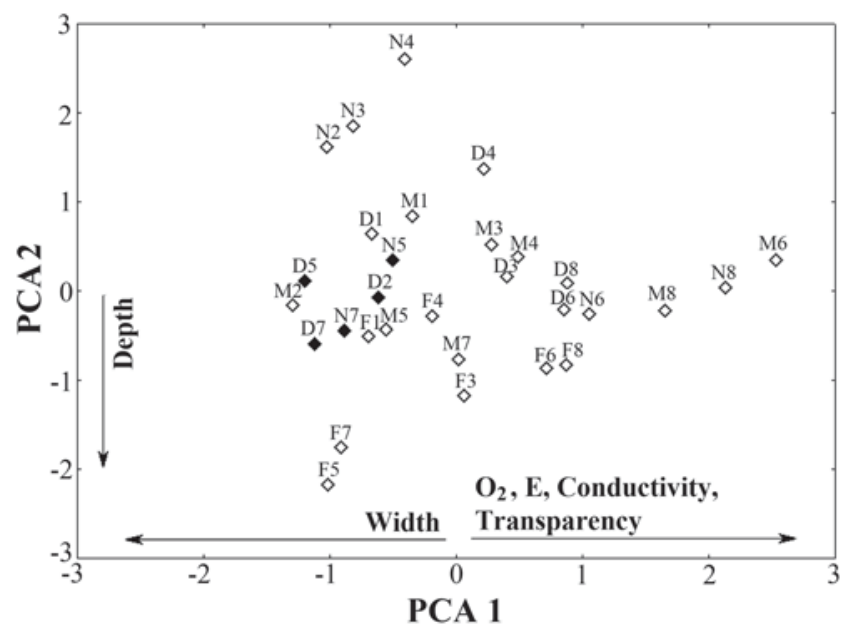

Fig. 5. Principal Components Analysis (PCA) of the matrix of environmental variables recorded in the headwaters of the Cuiabá River in November (N), December 2007 (D), January (J), February (F), and March 2008 (M). Numbers following months represent sites: $1=\mathrm{CBZ}$ I, $2=\mathrm{CBZ}$ II, $3=\mathrm{AFS}, 4=\mathrm{CBS}$, $5=\mathrm{CBZ}$ III, $6=\mathrm{TRS}, 7=\mathrm{CBZ}$ IV, $8=\mathrm{QBS}$. Dark symbols represent collections with highest density of ichthyoplankton. identified on a generic level (Apteronotus spp.) (Table 1).

The groups that presented a higher percentage of capture than 1\% were Anostomidae, Bryconamericus spp., Siluriformes, Pimelodidae, Pimelodus spp., Z. zungaro and Auchenipteridae. However, it should be noted that among the Siluriformes that could not be identified, there may have been larvae of Pimelodidae and Pimelodus spp., and among the Pimelodidae there may have been larvae of this genus. This is because many of the larvae were in stages of development that made it impossible to identify them at a lower taxonomic level.

The temporal analysis of groups with the highest density indicated that Siluriformes was the most frequent, with high rates of capture in the first four sampling months, but was not observed in March. Auchenipteridae were the taxa captured in all the collection months, with the highest frequency in March. Pimelodidae and Pimelodus spp. were captured in the first three months of sample collection, with the highest capture frequency in November. Zungaro zungaro was captured in December (the month in which it was the most frequent), January and February. Anostomidae presented captures in the last four months, and Bryconamericus spp. were captured in every month except February (Fig. 6a).

With regard to spatial distribution, Siluriformes was found to be present at all the sampling sites, but with a very low frequency at CBZ I, and predominantly at QBS (despite the low density at this sampling point). Auchenipteridae was not captured at sites CBS and QBS, and despite its low density, it was found most frequently at AFS. The captures of Pimelodidae were all concentrated at the sampling sites in Cuiabazinho River (highest frequency at CBZ I), and that of Pimelodus spp. at sites CBZ II, III and IV. Zungaro zungaro larvae were captured at sites CBS and CBZ II, and were more frequent at the latter point. Anostomidae was captured principally at CBZ I, with low frequency at the other sampling sites (CBS, CBZ II and CBZ IV). Bryconamericus spp. was captured at TRS, where it was more frequent, and at all the sampling sites in the main river (Fig. 6b). None of the most abundant groups differed significantly among the sampling months. However, Bryconamericus spp., Siluriformes, Auchenipteridae, Pimelodidae and Pimelodus spp. differed significantly among the sampling sites, with the highest densities observed at the sites in Cuiabazinho River (Table 2).

\section{Discussion}

Essential fish habitats (EFHs) are defined as water bodies and substrata required for spawning, reproduction, food and growth, and the evaluation of these habitats is essential in planned management (Bilkovic et al., 2002). The much higher density of eggs than of larvae indicates that the region under study can be considered a spawning area. In the floodplain of the Paraná River, Nakatani et al. (1997) found that the highest densities of eggs increased in the direction of the headwaters of the river's tributaries and that larval density followed an inverse trend. In the Pantanal floodplain there is evidences of 
Table 1. Taxonomic groups of larvae (classification according to Reis et al., 2003), with their respective total numbers of capture $(\mathrm{N})$, percentage of capture; $(\% \mathrm{C})$ and mean density, collected in the headwaters of the Cuiabá River from November 2007 to March 2008. * = individuals identified only to the order level; ** = individuals identified only to the family level; *** $=$ individuals identified only to the subfamily level.

\begin{tabular}{|c|c|c|c|c|c|c|c|c|}
\hline \multirow{2}{*}{ Taxonomic groups } & \multirow{2}{*}{$\mathrm{N}$} & \multirow{2}{*}{$\% \mathrm{C}$} & \multicolumn{6}{|c|}{ Months } \\
\hline & & & N/07 & $\mathrm{D} / 07$ & $\mathrm{~J} / 08$ & $\mathrm{~F} / 08$ & $\mathrm{M} / 08$ & Total \\
\hline Characiformes* & 1 & 0.10 & & 0.02 & & & & 0.02 \\
\hline \multicolumn{9}{|l|}{ Prochilodontidae } \\
\hline Prochilodus lineatus & 6 & 0.57 & & 0.06 & & & & 0.06 \\
\hline Anostomidae ${ }^{* *}$ & 39 & 3.73 & & 0.27 & 0.64 & 0.02 & 0.05 & 0.98 \\
\hline Characidae** & 2 & 0.19 & & & 0.03 & 0.02 & & 0.05 \\
\hline Bryconamericus spp. & 11 & 1.05 & 0.12 & 0.01 & 0.02 & & 0.10 & 0.25 \\
\hline Salminus brasiliensis & 3 & 0.29 & & 0.04 & & & & 0.04 \\
\hline Serrasalminae $* * *$ & 2 & 0.19 & & & 0.01 & & 0.03 & 0.04 \\
\hline Characinae $* * *$ & 1 & 0.10 & 0.26 & & & & & 0.26 \\
\hline Siluriformes* & 672 & 64.31 & 1.77 & 1.75 & 6.11 & 0.29 & & 9.91 \\
\hline \multicolumn{9}{|l|}{ Trichomycteridae } \\
\hline Trichomycterus spp. & 1 & 0.10 & 0.05 & & & & & 0.05 \\
\hline Heptapteridae** & 8 & 0.77 & 0.02 & 0.07 & 0.33 & 0.02 & 0.02 & 0.46 \\
\hline Pimelodidae $* *$ & 35 & 3.35 & 0.32 & 0.05 & 0.33 & & & 0.70 \\
\hline Hemisorubim platyrhynchos & 1 & 0.10 & & & 0.02 & & & 0.02 \\
\hline Megalonema platanum & 1 & 0.10 & & & 0.02 & & & 0.02 \\
\hline Pimelodus spp. & 46 & 4.40 & 0.52 & 0.30 & 0.05 & & & 0.87 \\
\hline Pseudoplatystoma spp. & 3 & 0.29 & 0.03 & & 0.01 & & & 0.04 \\
\hline Zungaro zungaro & 34 & 3.25 & & 0.39 & 0.06 & 0.03 & & 0.48 \\
\hline Auchenipteridae** & 83 & 7.94 & 0.19 & 0.19 & 0.27 & 0.11 & 0.16 & 0.91 \\
\hline Gymnotiformes* & 5 & 0.48 & 0.09 & 0.02 & 0.03 & & 0.01 & 0.16 \\
\hline \multicolumn{9}{|l|}{ Apteronotidae } \\
\hline Apteronotus spp. & 1 & 0.10 & & & 0.01 & & & 0.01 \\
\hline Damaged & 87 & 8.33 & 0.01 & 0.07 & 0.71 & 0.04 & & 0.83 \\
\hline Non-identified & 3 & 0.29 & & & & 0.03 & 0.01 & 0.04 \\
\hline Total & 1045 & 100 & & & & & & \\
\hline
\end{tabular}

the existence of a similar pattern, since large numbers of larvae of migratory species were found in stretches of the Cuiabá River downstream from the region of study of this work (Laboratório de Ecologia e Manejo de Recursos PesqueirosLEMARPE/UFMT unpublished data), in addition to larvae in more advanced stages of development in marginal lakes in the floodplain of the Cuiabá River (Tondato et al., 2010). These findings are indicative of a large number of EFHs in the Cuiabá River, including its headwater environments, which are important for the maintenance of fish stocks in the Pantanal.

Several studies (Machado-Allison, 1990; Humphries et al., 1999; Castro et al., 2002) have showed that the reproduction of floodplain fishes is highly seasonal, coinciding with the first flood phases (Welcomme, 1979). It is believed that, in neotropical species, biological events such as gonad maturation, migration and spawning are synchronized by the variation in water level and flow volume (Humphries et al., 2002). Therefore, the negative correlation with the river level and outflow and the fact that higher egg densities were observed in the month when these two variables were on the rise (December) may be an indication that spawning in the study environment is induced by the increased rates of this variables. The highest larval densities in January (despite the absence of significant differences among the months) confirms that the pattern found is due to the fact that most of the spawning occurred shortly before the flood period, which is favorable for larval development. In the upper Paraná River, the highest larval densities were found between January and February, coinciding with the flood period on the plains (Oldani et al., 1992).

The absence of a correlation between larval density and regional variables indicates that these variables affect egg distribution mainly, because they directly influence the spawning activity of fish. According to the match/mismatch hypothesis (Cushing, 1975), the temporal distribution of fish larvae depends on the presence of food in the environment since food, growth and survival are optimized where there is a balance between the interval when larvae begin exogenous feeding and the availability of prey of suitable size in the environment. Due to the short larval period of most tropical freshwater species, it makes sense that reproduction should include adaptations linked principally to food supply for juveniles and adults (Reynalte-Tataje, 2007). Therefore, other variables such as the presence of food, predation and competition (Harvey, 1991; Pavlov et al., 2008), and even the feeding strategy of adults (Reynalte-Tataje, 2007), may influence the temporal distribution of larvae.

The highest egg and larval densities were related to sites with lower values of dissolved oxygen, conductivity and transparency, greater river widths and intermediate depths. It is known that high concentrations of dissolved oxygen are necessary for the satisfactory development of fish eggs (Werner, 2002). However, in the study environment, dissolved oxygen seems not to be a limiting factor for spawning, since all the sites showed high concentrations.

Electrical conductivity acts as a synchronizing factor for final 


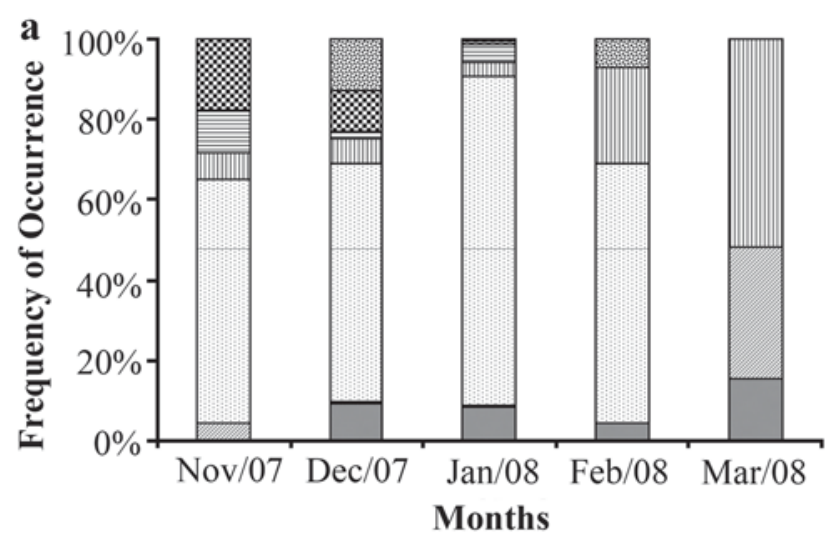

图 Z. zungaro

曰 Pimelodidae

$\square$ Siluriformes

$\square$ Anostomidae

b

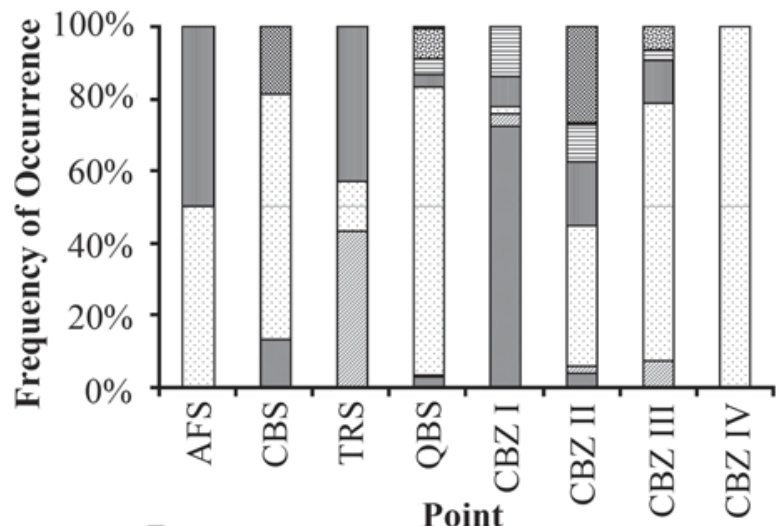

-Z. zungaro

曰Pimelodidae

口Siluriformes

$\square$ Anostomidae

هPimelodus spp.

$\square$ Auchenipteridae

-Bryconamericus spp.

Fig. 6. Temporal (a) and spatial (b) frequency of occurrence of the seven most abundant taxa of fish larvae captured in the headwaters of the Cuiabá River between November 2007 and March 2008.

maturation, spawning and fertilization (Vazzoler, 1996). In the floodplain of the upper Paraná River, conductivity was found to be positively correlated with ichthyoplankton density (Baumgartner et al., 1997). However, the values these authors reported were not as high as those recorded in the present work. Here, low densities were found at sites with very high values of conductivity (CTR and CQB tributaries), which suggests that such extremes may be deleterious for the development of ichthyoplankton. This high values of electrical conductivity, as well as observed with $\mathrm{pH}$ maybe explained by the local sedimentary basis, which is formed principally by calcareous.

In more transparent waters, i.e., with lower amounts of suspended solids, eggs and larvae are more vulnerable to predation (Sanches et al., 2006). The reduction of water transparency caused by the retention of sediments by dams is one of the main factors that explain the decline of migratory
Table 2. Results of the Kruskall-Wallis (H) and Mann-Whitney (U) tests applied to the most abundant taxonomic groups captured in the headwaters of the Cuiabá River between November 2007 and March 2008. (*) indicates significant differences ( $\mathrm{p}<0.025$, corrected by Bonferroni's Correction).

\begin{tabular}{lcccc}
\hline \multirow{2}{*}{ Group } & \multicolumn{2}{c}{ Month } & \multicolumn{2}{c}{ Point } \\
\cline { 2 - 5 } \multicolumn{1}{c}{$\mathrm{H}$} & $\mathrm{p}$ & $\mathrm{U}$ & $\mathrm{p}$ \\
\hline Anostomidae & 4.24 & 0.37 & 2.39 & 0.04 \\
Bryconamericus spp. & 4.64 & 0.32 & $2.47(*)$ & $0.02\left(^{*}\right)$ \\
Siluriformes & 8.94 & 0.06 & $2.69(*)$ & $0.01\left(^{*}\right)$ \\
Auchenipteridae & 1.02 & 0.91 & $3.25(*)$ & $0.00(*)$ \\
Pimelodidae & 9.21 & 0.05 & $2.60\left(^{*}\right)$ & $0.00(*)$ \\
Pimelodus spp. & 6.34 & 0.17 & $2.40(*)$ & $0.01\left(^{*}\right)$ \\
Zungaro zungaro & 3.58 & 0.46 & 2.10 & 0.28 \\
\hline
\end{tabular}

species downstream from them (Petrere Jr., 1996). Therefore, a possible explanation for the reduced egg and larval density in the tributaries sampled in this study is the high transparency of the water observed in these sites.

The narrowest and least deep sampling sites (characteristics observed in the tributaries) seem not to provide adequate conditions for parents in the period of spawning and/or larval drift. However, the reproductive activity may have already been declining in the months with the highest river levels (February and March). Peaks in river level seem to be a signal to end spawning (Suzuki et al., 2004; Bailly et al., 2008), which explains the low density at the sites of greater depth. Egg and larval densities were significantly higher at the sites in the main river, indicating that spawning and drift occurs preferentially in the main channel of the Cuiabazinho River.

Spatially, the egg distribution gradient suggests that the migrations do not reach the upper portions of the river, and that spawning occurs more intensely in the lower portions of the headwaters, where the adults probably already find suitable environmental conditions for spawning and spatial locations that favor egg drifting to growth environments. The distance from the spawning site to growth sites may represent a restriction in the recruitment of stocks, since the risk of mortality increases at long distances due to physical damage sustained in the drifting process, and especially due to lack of food (Jones et al., 2003). No spatial distribution pattern was found for larvae. These findings are similar to those reported in two rivers in the state of Virginia, USA, that were characterized as spawning sites and not as natural fish nurseries (Bilkovic et al., 2002).

Identification of the community composition of fish larvae in the present study was impaired because most of the captured larvae were newly hatched and also because of the paucity of reference material and the absence of identification keys to the larvae of the region's species. Therefore, a large part of the material was identified only down to family level, and the group with highest contribution (Siluriformes) only down to order level. The highest larval density was of sedentary species that do not make extensive reproductive migrations $(77.29 \%$, without considering Characiformes, Siluriformes, Anostomidae and Pimelodidae), and which may therefore spend their entire life cycle in the region. However, the presence of larvae of migratory 
species (Prochilodus lineatus, Salminus brasiliensis, Hemisorubim platyrhinchos, Pseudoplatystoma spp. and Zungaro zungaro), which accounted for $22.70 \%$ of the total number of identified larvae, allows us to state that the region is also an important area of reproduction for these species. To the fish species of the floodplain of Paraná River, 83.8\% presented sedentary habits compared to $16.2 \%$ that engage in long reproductive migrations (Suzuki et al., 2004). The predominance of larvae of sedentary species in the ichthyoplankton was also observed in the Baía River, in the floodplain of upper Paraná River (Bialetzki et al., 2005).

Bryconamericus spp., Siluriformes, Auchenipteridae, Pimelodidae and Pimelodus spp. presented significantly higher capture densities in the main river; hence, the adults of these groups reproduce preferentially in this type of environment. Larvae of the large migratory species $Z$. zungaro were captured exclusively at sites CBZ II and CBS, which are geographically very close to each other, indicating that this is the principal area of reproduction of the species in the study region, and that adults also use this tributary to reproduce. The period of highest captures of Anostomidae (December to March) corresponded to the period of reproduction reported in the literature (Vazzoler, 1996). The point with the highest density of larvae from this family was CBZ I, which indicates that the location further upstream from the study region has been used mainly for the reproduction of species that live there or that make minor reproductive migrations, which is characteristic of fishes of this family (Vazzoler, 1996).

Based on these findings, it can be stated that the study area is an important spawning area for the fish species of the region, and that the larvae originating from the spawn of migratory fishes are probably being transported downriver to sites suitable for their development. Considering the set of variables that influence the choice of spawning site, the Cuiabazinho River, rather than its tributaries, appears to be the most suitable habitat for the reproduction of most of the species, underscoring the importance of maintaining the integrity of this environment. However, one cannot disregard the importance of the tributaries for the reproduction of the region's fish, firstly because some species appear to have an affinity for reproducing in the tributaries, such as the migratory species $Z$. zungaro, and secondly because these rivers are important for maintaining the hydrology and dynamics of the Cuiabazinho River.

\section{Acknowledgements}

The authors would like to thank Centro de Pesquisa do Pantanal (CPP)/MCT for their financial, human and logistic support, CNPq for granting a master's scholarship and SEMAMT for their availability of environmental data.

\section{Literature Cited}

Agostinho, A. A. \& H. F. Júlio Jr. 1999. Peixes da bacia do Alto rio Paraná. Pp. 374-00. In: Lowe-McConnell, R. H. (Ed.). Estudos
Ecológicos de Comunidades de Peixes Tropicais. São Paulo, Edusp, 534p.

Bailly, D., A. A. Agostinho \& H. I. Suzuki. 2008. Influence of the flood regime on the reproduction of fish species with different reproductive strategies in the Cuiabá river, upper Pantanal, Brazil. River Research and Applications, 24: 1218-1229.

Baumgartner, G., K. Nakatani, M. Cavicchioli \& M. S. T. Baumgartner. 1997. Some aspects of the ecology of fish larvae in the floodplain of the high Paraná river, Brazil. Revista Brasileira de Zoologia, 24: 551-563.

Bialetzki, A., K. Nakatani, P. V. Sanches \& G. Baumgartner. 2004. Eggs and larvae of the "curvina" Plagioscion squamosissimus (Heckel, 1840) (Osteichthyes, Sciaenidae) in the Baía River, Mato Grosso do Sul State, Brazil. Journal of Plankton Research, 26: 1327-1336.

Bialetzki, A., K. Nakatani, P. V. Sanches, G. Baumgartner \& L. C. Gomes. 2005. Larval fish assemblage in the Baía River (Mato Grosso do Sul State, Brazil): temporal and spatial patterns. Environmental Biology of Fishes, 73: 37-47.

Bilkovic, D. M., C. H. Hershner \& J. E. Olney. 2002. Macroscale assessment of american shad and nursery habitat in the Mattaponi and Pamunkey Rivers, Virginia. North American Journal of Fisheries Management, 22: 1176-1192.

Castro, R. J., K. Nakatani, A. Bialetzki, P. V. Sanches \& G. Baumgartner. 2002. Temporal distribution and composition of the ichthyoplankton from Leopoldo's Inlet on the upper Parana River floodplain (Brazil). Journal of Zoology, 256: 437-443.

Cavinatto, V. 1995. Caracterização Hidrográfica do Estado de Mato Grosso. Cuiabá, Prodeagro/Seplan/Fema-MT.

Copp, G. H. 1992. Comparative microhabitat use of cyprinid larvae and juveniles in a lotic floodplain channel. Environmental Biology of Fishes, 33: 181-193.

Cushing, D. H. 1975. Marine Ecology and Fisheries. Cambridge, Cambridge University Press, 278p.

Gomes, L. C. \& A. A. Agostinho. 1997. Influence of flooding regime on the nutritional state and juvenile recruitment of the curimba Prochilodus scrofa, Steindachner, in the upper Paraná River, Brazil. Fisheries Management and Ecology, 4: 263-274.

Harvey, B. C. 1991. Interaction of abiotic and biotic factors influences larval fish survival in an Oklahoma stream. Canadian Journal of Fisheries and Aquatic Science, 48: 1476-1480.

Humphries, P., A. J. King \& J. D. Koehn. 1999. Fish, flows and flood plains: links between freshwater fishes and their environment in the Murray-Darling river system, Australia. Environmental Biology of Fishes, 56: 129-151.

Humphries, P., L. G. Serafini \& A. J. King. 2002. River regulation and fish larvae: variation through space and time. Freshwater Biology, 47: 1307-1331.

Jackson, D. A. 1993. Stopping rules in principal components analysis: a comparison of heuristical and statistical approaches. Ecology, 74: 2204-2214.

Jones, M. L., J. K. Netto, J. D. Stockwell \& J. B. Mion. 2003. Does the value of newly accessible spawning habitat for walleye (Stizostedion vitreum) depend on its location relative to nursery habitats? Canadian Journal of Fisheries and Aquatic Sciences, 60: $1527-1538$

Jonsson, N. 1991. Influence of water flow, water temperature and light on fish migrations in rivers. Nordic Journal of Freshwater Research, 66: 20-35.

Lowe-McConnell, R. H. 1999. Estudos Ecológicos de Comunidades de Peixes Tropicais. São Paulo, EDUSP, 534p. 
Machado-Allison, A. 1990. Ecologia de los peces de las áreas inundables de los llanos de Venezuela. Interciencia, 15: 411-421.

Nakatani, K., G. Baumgartner \& M. Cavicchioli. 1997. Ecologia de ovos e larvas de peixes. Pp. 281-306. In: Vazzoler, A. E. A. M., A. A. Agostinho \& N. S. Hahn (Eds.). A Planície de Inundação do Alto Rio Paraná: Aspectos Físicos, Biológicos e Socioeconômicos. Maringá, Eduem, 460p.

Nakatani, K., A. A. Agostinho, G. Baumgartner, A. Bialetzki, P. V. Sanches, M. C. Makrakis \& C. S. Pavanelli. 2001. Ovos e Larvas de Peixes de Água Doce: Desenvolvimento e Manual de Identificação. Maringá, Eduem, 378p.

Oldani, N. O., J. M. Iwaszkim, O. H. Pandim \& A. Otaegui. 1992. Flutuaciones de la abundancia de peces en el Alto Paraná (Corrientes, Argentina). Publicaciones de la Comisión Administradora del Río Uruguay, 1: 43-55.

Pavlov, D. S., A. M. Pakhorukov, G. N. Kuragina, U. K. Nezdoliy, N. P. Nekrasova, D. A. Brodskiy \& A. L. Ershler. 1978. Some features of the downstream migrations of juvenile fishes in the Volga and Suban Rivers. Journal of Ichthyology, 19: 363-374.

Pavlov, D. S., V. N. Mikeev, A. I. Lupandin \& M. A. Skorobogatov. 2008. Ecological and behavioral influences on juvenile fish migrations in regulated rivers: a review of experimental and field studies. Hydrobiologia, 60: 125-138.

Penáz, M., A. L. Roux, P. Jurajda \& J. M. Olivier. 1992. Drift of larval and juvenile fishes in a by-passed floodplain of the upper River Rhone, France. Folia Zoologica, 41: 281-288.

Petrere Jr., M. 1996. Fisheries in large tropical reservoirs in South America. Lakes \& Reservoirs: Research and Management, 2: 111-113.

Reis, R. E., S. O. Kullander \& C. J. Ferraris Jr. 2003. Check List of the Freshwater Fishes of South and Central America. Porto Alegre, EDIPUCRS, 739p.

Reynalte-Tataje, D. A. 2007. Influência inter e intra anual de variáveis ambientais sobre a estrutura da comunidade ictioplanctônica em duas bacias hidrográficas brasileiras. Unpublished Ph.D. Dissertation, Universidade Estadual de Maringá, Maringá. 116p.
Sanches, P. V., K. Nakatani, A. Bialetzki, G. Baumgartner, L. C. Gomes \& E. A. Luiz. 2006. Flow regulation by dams affecting ichthyoplankton: the case of the Porto Primavera Dam, Paraná River, Brazil. River Research and Applications, 22: 555-565.

Statsoft. 1999. Statistica: Quick Reference. Tulsa, Stat-Soft.

Suzuki, H. I., F. M. Pelicice, E. A. Luiz, J. D. Latini \& A. A. Agostinho. 2004. Reproductive Strategies of the Fish Community of the Upper Paraná River Floodplain. Pp. 125130. In: Agostinho, A. A., L. Rodrigues, L. C. Gomes, S. M. Thomaz \& L. E. Miranda (Eds.). Structure and Functioning of the Paraná River and its Floodplain. Maringá, Eduem, 275p.

Tanaka, S. 1973. Stock assessment by means of ichthyoplankton surveys. FAO Fisheries Technical Papers, 122: 33-51.

Tondato, K. K., L. A. F. Mateus \& S. R. Ziober. 2010. Spatial and temporal distribution of fish larvae in marginal lagoons of Pantanal, Mato Grosso State, Brazil. Neotropical Ichthyology, 8: 123-133.

Vazzoler, A. E. A. M. 1996. Biologia da Reprodução de Peixes Teleósteos: Teoria e Prática. Maringá, Eduem, 169p.

Welcomme, R. L. 1979. Fisheries Ecology of Floodplain Rivers. London, Logman, 317p.

Werner, R. G. 2002. Habitat requirements. Pp. 161-182. In: Fuiman, L. A., R. G. Werner (Eds.). Fishery Science: The Unique Contributions of Early Life Stages. Oxford, Blackwell Sciences, 326p.

Wilkinson, L. 2007. SYSTAT: the Systems for Statistics Version 12.0. San Jose, Software Inc.

Zaniboni-Filho, E. \& U. H. Schulz. 2003. Migratory fishes of the Uruguay river. Pp. 157-194. In: Carolsfeld J., B. Harvey, C. Ross \& A. Baer (Eds.). Migratory Fishes of the South America: Biology, Social Importance and Conservation Status. Victoria, World Fisheries Trust, 372p.

Ziober, S. R., A. Bialetzki, L. C. Gomes \& D. Kipper. 2007. The importance of a marginal lagoon as a fish nursery in the Upper Paraná River floodplain. Acta Limnologica Brasiliensia, 19(4): 369-381.

Submitted February 14, 2011

Accepted October 17, 2011

Published March 30, 2011 